\title{
A BRONZE FIGURINE OF MINERVA DISCOVERED AT APULUM
}

\author{
RADU OTA - ADRIAN COSMIN BOLOG
}

National Museum of the Union

12-14 Mihai Viteazul street,

RO 510010 Alba Iulia, Romania

eractum@yahoo.com

adrian_bolog@yahoo.com

\begin{abstract}
The authors discuss herein, and present the specialists, a recent find related to the classical Graeco-Roman pantheon. It is a bronze figurine of Minerva discovered in a waste pit from the southern cemetery of the urban centre at Apulum, located on the Furcilor Hill-"Podei". Although archaeology records no workshop making such pieces, this figurine, rather modest in artistic terms, had likely been produced at Apulum or in one of the workshops from the Roman province of Dacia. It is a solid cast, in the "lost-form" technique, sized as follows: height $-7.2 \mathrm{~cm}$, width $-1.9 \mathrm{~cm}$, thickness $-0.9 \mathrm{~cm}$. On the basis of its execution, which lacks accurate rendering of facial features, yet also the absent Gorgon on the aegis, the votive figurine may be dated to the $3^{\text {rd }}$ century AD. Since it was not discovered in a grave, but in a waste pit, it is rather difficult to make a connection with any possible funerary function of the goddess. The ancient prototype of this kind of representation is the cult statue of Athena Parthenos of Phidias, housed on the Acropolis of Athens. The other six bronze votive figurines of Minerva discovered in Dacia do not resemble that discussed here.
\end{abstract}

Keywords: bronze figurine, the southern cemetery, Minerva, municipium Septimium Apulense

\section{INTRODUCTION}

Yearly, the rescue archaeological excavations yield new evidence of inhabitancy in ancient Apulum, the most important urban centre of the Roman province of Dacia. We shall discuss herein a recent find related to the cults of the classical Graeco-Roman pantheon, namely an interesting votive figurine of Minerva, worked of bronze, discovered in 2008 by the northern edge of the Roman cemetery from the Furcilor Hill-"Podei".

Subsequent to the construction of the Roman fortress of XIII Gemina two settlements that rose to urban status following gradual development had been founded there as early as Trajan: 1 . The canabae legionis established around the Roman camp, which under Septimius Severus became a municipium; 2. A pagus of Ulpia Traiana Sarmizegetusa, lying to the left of the Mureș, ancient Maris, developed over the time so much that it was awarded the status of a municipium under Marcus Aurelius and that of a colonia during his successor, Commodus. ${ }^{1}$ In the eastern quarters of the canabae, the governors' palace of Roman Dacia was built no later than the rule of Marcus Aurelius, once with the political and military reorganization which the emperor undertook in AD $169 .{ }^{2}$ An inscription dated to AD 252-253 proves yet again the exceptional economic and constructional development of the town, namely the epithet Chrysopolis - "golden city" - which enriches the town's title. ${ }^{3}$ Both towns, by their spatial extension, yet especially the structure of the buildings and richness of the heritage revealed by the archaeological excavations, represent the most important urban centres of Roman Dacia.

${ }^{1}$ ARDEVAN 1998, 45-46; OTA 2012.

${ }^{2}$ Diaconescu-Piso 1993, 72-73; Rusu-BolindeT et al. 2011.
${ }^{3}$ IDR III/5, 332-333, no. 432.

Acta Archaeologica Academiae Scientiarum Hungaricae 70 (2019) 317-324 0001-5210 @ 2019 Akadémiai Kiadó, Budapest 
Minerva was the deity of wisdom, also known by the Etruscans as Menerva or Menrva. The deity's role was to protect the soldiers, arts, crafts and trade. ${ }^{4}$ In Rome Minerva is worshipped in the temple of the Capitoline Triad on the Capitoline Hill and in other temples dedicated to the goddess, on the Caelian and Aventine Hills. ${ }^{5}$

At Apulum, the cult of Minerva is recorded by several epigraphic representations ${ }^{6}$ that include a clay votive figurine $^{7}$ and several stone sculptural monuments: a relief on a votive marble plaque, which comes from colonia Aurelia Apulensis, ${ }^{8}$ a marble votive figurine ${ }^{9}$ and one intaglio, with unknown findspot, which comes from a private collection. ${ }^{10}$

\section{FIND CONTEXT}

The figurine was discovered during an archaeological rescue excavation conducted in an area by the northern edge of the southern cemetery of the urban centre at Apulum. ${ }^{11}$ This burial area lies between the two Roman towns. The figurine was recovered from a pit noted $\mathrm{C} 19$, at $-1.60 \mathrm{~m},{ }^{12}$ which consisted of several filling levels. It was used as a waste pit, most likely during funerary feasts, its inventory with a large quantity of sacrificed domestic animal bones and pottery. Later, the feature was overlapped by three inhumation graves without grave goods (Fig. 1).

\section{FIGURINE DESCRIPTION AND PARALLELS}

The figurine is solid cast (inv. no. R10653), in the "lost-form" technique and is the product of a provincial workshop. Its sizes are as follows: $\mathrm{h}-7.2 \mathrm{~cm} ; 1-1.9 \mathrm{~cm}$; weight $-0.9 \mathrm{~cm}$ height $-7.2 \mathrm{~cm}$, width $-1.9 \mathrm{~cm}$, thickness $-0.9 \mathrm{~cm}$. To date, such workshop could not be identified at Apulum, although its existence was supposed. ${ }^{13}$ The goddess wears a peplos, fastened below the chest with a string, which covers entirely her legs. In the neck area, the cut is "V"-shaped. The garment is pinned on shoulders with brooches and hangs down to the hips area. On the chest is rendered the aegis, delimited by two serpents, yet without the face of Gorgon Medusa (gorgoneion). The key attributes, the spear and shield no longer survive. In the right hand, raised, the goddess holds the spear, and in the other, bent at elbow, the shield. The insertion orifice of the spear through the clasped fist of the hand is still visible. On the head the deity wears a crested Corinthian helmet. The helmet exhibits an interesting detail, which could not be found in any other figurine of Minerva, namely, a stamped decoration consisting of stellar signs: three half-moons on the left side and three circles on the right side. The portrait is rather coarse, with eyes of different sizes, bulging, and projecting orbit. The hair may be distinguished exiting from under the helmet and is rendered following the orbits outline. Body weight rests on the left, extended leg. The right leg is slightly drawn back, thus creating the contrapposto effect. In general, the artistic level is inferior, much below the average at provincial level. Most likely, it comes from a workshop in Dacia (Figs 2-3)..$^{14}$

We could not identify identical parallels, yet instead, we found bronze figurines of Minerva with similar peculiarities. For instance, a figurine discovered at Ulpiana depicts the goddess wearing a similar peplos, with right hand raised, and the left at the side. ${ }^{15}$ Another found at Burnum, in the region of Liburnia, exhibits resembling features of the attire and the same position of the arms. ${ }^{16}$ At Volubilis, in Mauretania Tingitana, a bronze figurine of Minerva has a similar garment. ${ }^{17}$ The two figurines from Augusta Treverorum, in Gallia Belgica, resemble by only

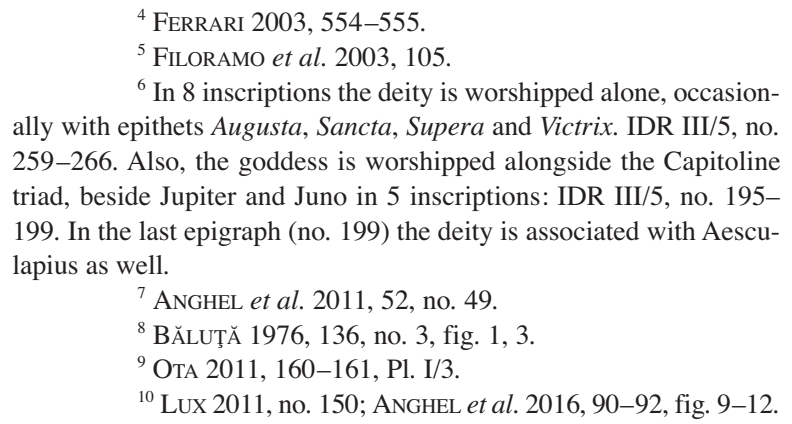

${ }^{6}$ In 8 inscriptions the deity is worshipped alone, occasionally with epithets Augusta, Sancta, Supera and Victrix. IDR III/5, no. 259-266. Also, the goddess is worshipped alongside the Capitoline triad, beside Jupiter and Juno in 5 inscriptions: IDR III/5, no. 195199. In the last epigraph (no. 199) the deity is associated with Aesculapius as well.

Acta Archaeologica Academiae Scientiarum Hungaricae 70, 2019

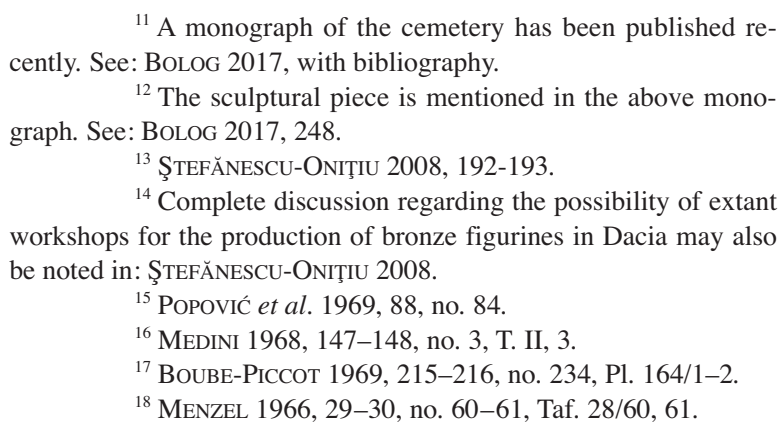

${ }^{11}$ A monograph of the cemetery has been published recently. See: BoLOG 2017, with bibliography.

${ }^{12}$ The sculptural piece is mentioned in the above monograph. See: BolOg 2017, 248.

${ }^{13}$ ŞTEFǍNESCU-ONIŢIU 2008, 192-193.

${ }^{14}$ Complete discussion regarding the possibility of extant workshops for the production of bronze figurines in Dacia may also be noted in: ŞTEFĂNESCU-ONIŢIU 2008.

${ }^{15}$ Popović et al. 1969,88 , no. 84.

${ }^{16}$ MedinI 1968, 147-148, no. 3, T. II, 3.

${ }^{17}$ Boube-Piccot 1969, 215-216, no. 234, Pl. 164/1-2.

${ }^{18}$ Menzel 1966, 29-30, no. 60-61, Taf. 28/60, 61. 


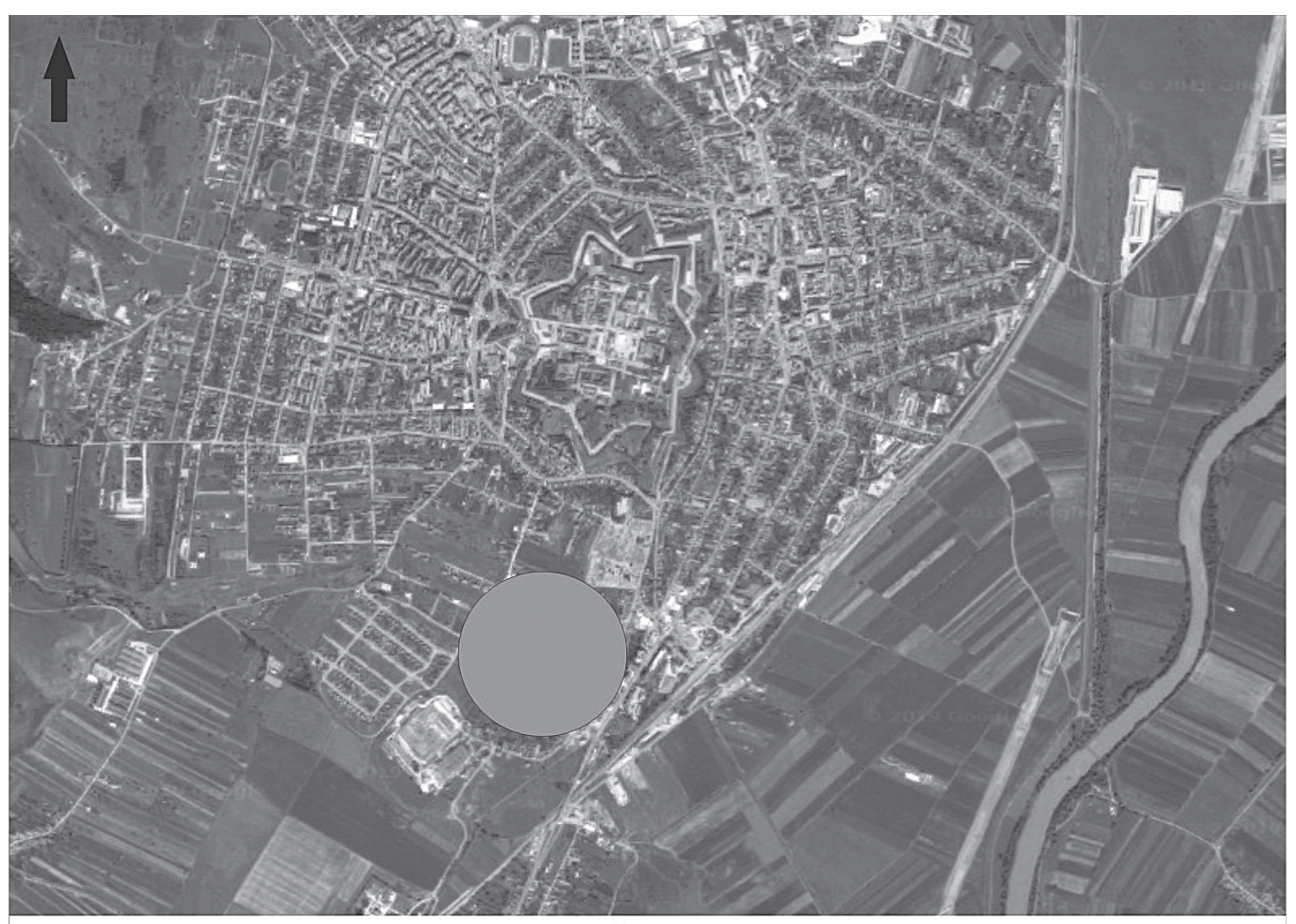

\section{A}

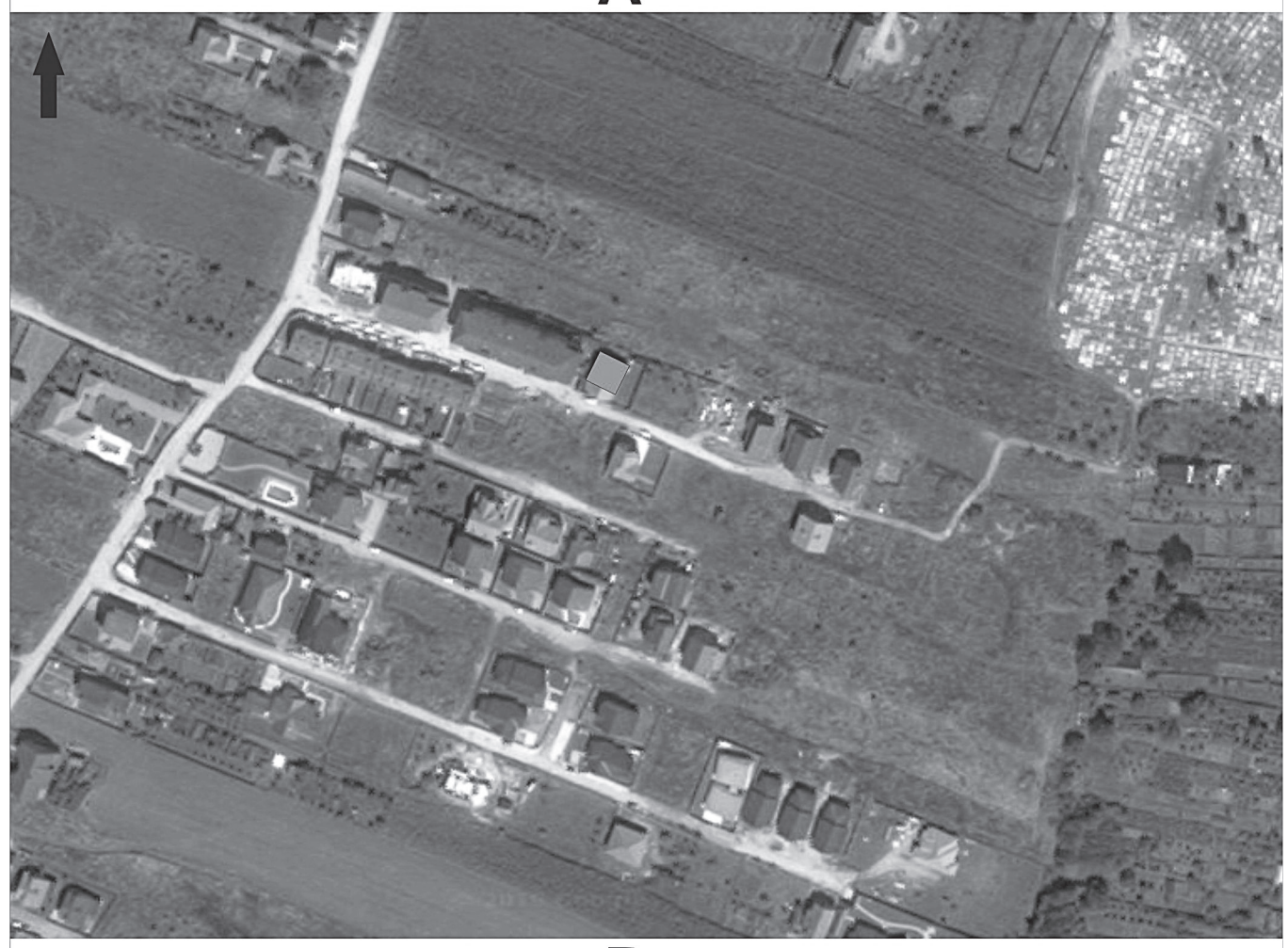

B

Fig. 1. A: Location of Roman necropolis from Apulum, Dealul Furcilor-"Podei”; $\mathrm{B}$ : The place where it was discovered the bronze figurine 

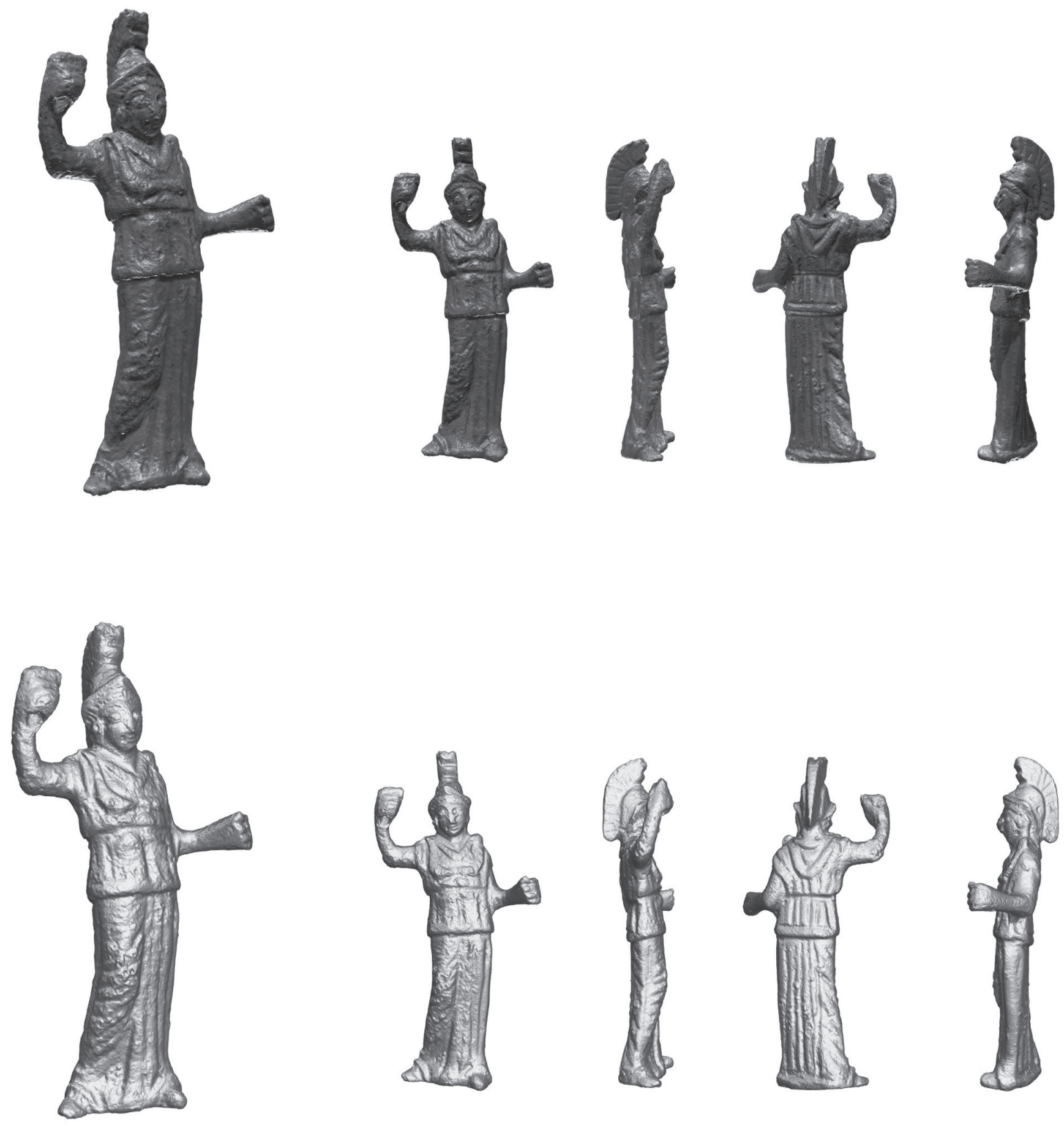

Fig. 2. Minerva statuette. Photos by Călin Şuteu

the position of the arms, and not the garments. ${ }^{18} \mathrm{~A}$ figurine coming likely from Germania inferior, housed with the Museum of Bonn, exhibits a peplos which much resembles the one herein. ${ }^{19}$ From northern Italy come three figurines iconographically similar, yet of higher quality in artistic terms, discovered at Tregnano and Verona (2). ${ }^{20}$ The votive figurines of Minerva from Dacia, six in number, ${ }^{21}$ do not resemble to that examined herein, thus not framing in the typological class suggested for Dacia by Lucia Tुeposu-Marinescu and Constantin Pop ${ }^{22}$ or for Germania superior by Annemarie Kaufmann-Heinimann. ${ }^{23}$

\footnotetext{
${ }^{19}$ Menzel 1969, 34, no. 21.

${ }^{20}$ BolLa 1999, 206-207, Fig. 33a-b, 34a-b, 35a-b.

${ }^{21}$ Theposu-Marinescu-Pop 2000, 76-79, no. 78-83, Pl. $43-45$.
}

\footnotetext{
${ }^{22}$ TुEPosu-Marinescu-PoP 2000, 79-80.

${ }^{23}$ Kaufmann-Heinimann 1977, 60-61.
} 


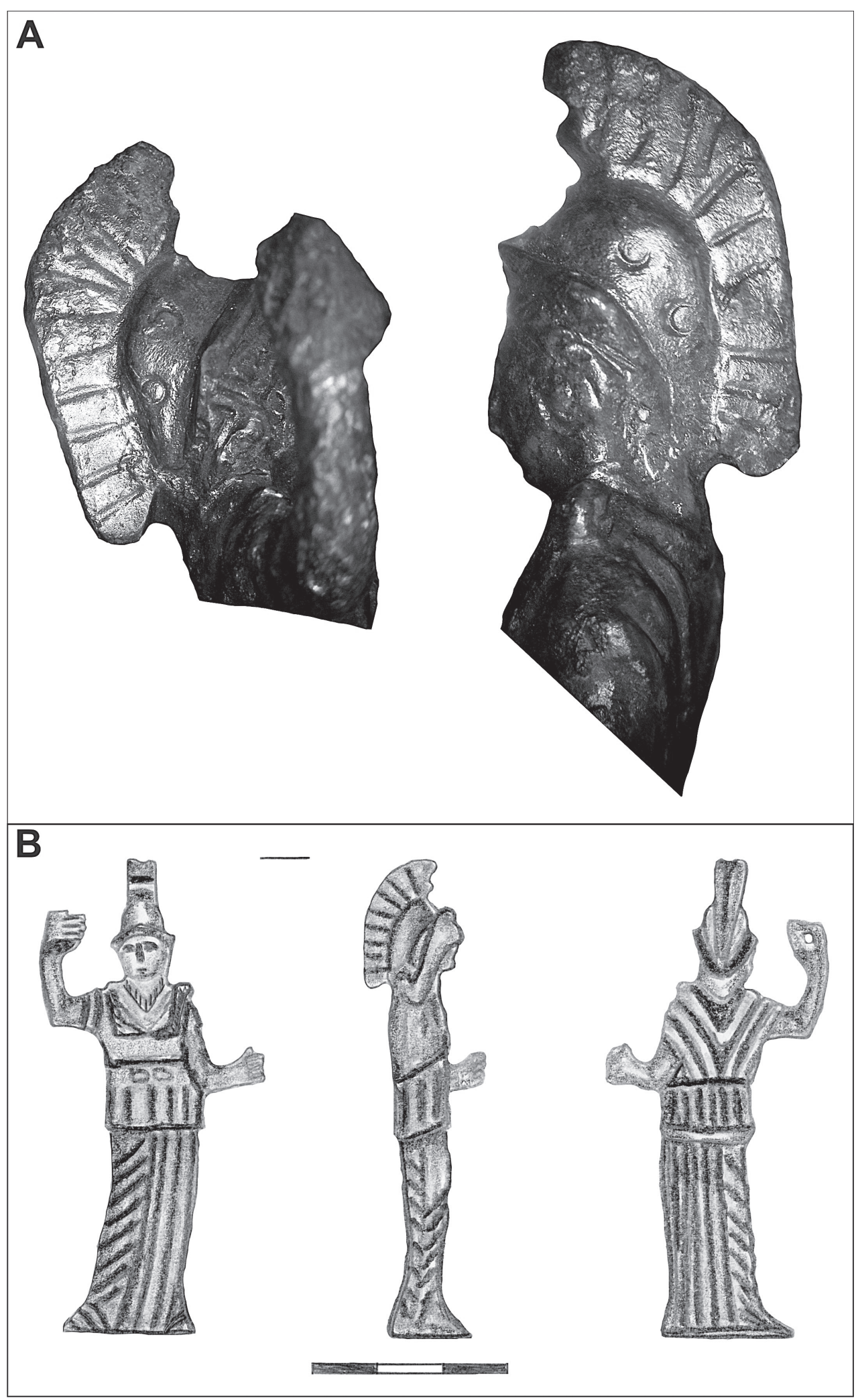

Fig. 3. A: Details of the helmet; B: Miverva statuette. Drawn by Călin Adam 
The votive figurine of Minerva is of a modest artistic quality, below the average provincial level. At Apulum, there is not a workshop making such specimens identified archaeologically, yet it cannot be excluded that the piece was produced there or in another provincial workshop from Dacia. It is certain though that it does not resemble any other bronze votive figurine of Minerva from Dacia. The pit in which it was found was a waste pit, with three filling levels, and it was overlapped by three inhumations without any grave goods. We do not suppose that the goddess fulfilled a funerary function, yet we do not know either the reason why it was cast away in the waste pit. It seems that in the pit there were cast remains of funerary feasts, as significant quantities of pottery and animal bones were recovered from there. As regards the chronological framing the context is not of much aid, as the pottery is common, while the graves which overlapped the archaeological feature lack any furnishing. Instead, it may be dated to the $3^{\text {rd }}$ century AD based on stylistic features, which reveal a primitive product with portrait features rendered unequally and asymmetrically and the aegis without the gorgoneion. The archaic prototype of this type of iconographic representation of Minerva is illustrated by the statue of Athena Parthenos of Phidias, housed on the Acropolis of Athens. ${ }^{24}$

The discovery of this bronze votive figurine of Minerva is yet another proof for the diffusion of the official cults of the Roman state. Furthermore, it is the first bronze figurine of the goddess found at Apulum to date and the fifth iconographic representation from this urban centre.

\section{REFERENCES}

ANGHEL et al. 2011

ANGHEL et al. 2016

ArdeVAn 1998

BĂLUŢĂ 1976

BENEA 2008

Bolla 1999

BoLOG 2017

Boube-Piccot 1969

Covacef 2002

DiAconescu-Piso 1993

FERRARI 2003

FILORAMO et al. 2003

IDR III/5, 1-2
= D. ANGHEL-R. OtA-G. BounEgru-I. LAscu: Coroplastica, medalioane şi tipare ceramice din colecţiile Muzeului Naţional al Unirii Alba Iulia [Roman Coroplastic, Ceramic Medaillons and Moulds from the Collection of the National Museum of the Union Alba Iulia]. Alba Iulia 2011.

= D. ANGHEL-N. HAR-C. ŞUTEU-M. URSU: Metode de investigare mineralogice şi petrografice ale unor intalii din colecţia Muzeului Naţional al Unirii din Alba Iulia [Mineralogical and petrographic investigation methods applied to intaglios from the Collection of the National Museum of Union, Alba Iulia]. TS 8 (2016) 83-104.

= R. ARDEVAN: Viaţa municipală în Dacia romană [Municipal Life in Roman Dacia].Timişoara 1998.

= C. I. BĂLUŢă: Plăci votive de la Apulum [Votive plaques from Apulum]. Apulum 14 (1976) 131-147.

= D. BENEA: Ateliere de prelucrare a bronzului, argintului şi aurului în Dacia Romană [Workshops for the processing of bronze, silver and gold in Roman Dacia]. In: Dacia în sistemul socio-economic roman. $\mathrm{Cu}$ privire la atelierele meşteşugăreşti locale [Dacia in the Roman Socio-Economic System. Regarding to the local workshops]. Eds.: D. Benea, S. Regep-Vlascici, M. Crînguş-Balaci, A. Ştefănescu-Oniţiu, C. Timoc. Bibliotheca historica et archaeologica Universitatis Timisiensis 9. Timişoara 2008, 107-180.

= A. Bolla: Bronzetti figurati romani del territorio Veronese. Rassegna di Studi del Civico Museo Archeologico e del Civico Gabinetto Numismatico di Milano 63-64 (1999) 193-261.

= A. BoloG: Necropola romană de la Apulum, Dealul Furcilor - „Podei” (campaniile 2008-2012) [Roman Necropolis from Apulum, Dealul Furcilor - „Podei”]. Cluj-Napoca 2017.

= C. Boube-PicCOT: Les bronzes antiques du Maroc. I. : La statuaire. Rabat 1969.

= Z. CovACEF: Arta sculpturală în Dobrogea romană. Secolele I-III [Sculptural Art in Roman Dobrogea. ${ }^{\text {st }}$ and III $^{\text {rd }}$ Centuries]. Cluj-Napoca 2002.

$=$ Al. DiAconescu-I. Piso: Apulum. In: La politique édilitaire dans les provinces de l'Empire romain. Actes du $1^{\text {er }}$ Colloque roumano-suisse, Deva 1991. Éds.: D. Alicu, H. Boegli. Cluj-Napoca 1993, $67-81$.

= A. FERRARI: Dicţionar de mitologie greacă şi romană [Dictionary of Greek and Roman Mythology]. Bucharest-Iaşi 2003.

= G. FilorAmo-M. MASSENZIO-M. RAVERI- P. SCAPRI: Manual de istorie a religiilor (Manuale storia delle religioni). Bucharest 2003.

= I. Piso (ed.): Inscriptiones Daciae Romanae. Inscriptions d'Apulum. III/5 : Apulum Daciaee Superioris. 1-2. Ed Paris 2001. 
Imperial Rome II 2002

KAUFMANN-HEINIMANN 1977

$\operatorname{Lux} 2011$

MEDINI 1968

MENZEL 1966

MENZEL 1969

ОтА 2011

ОTА 2012

PoPOVIĆ et al. 1969

RACHET-RACHET 1968

RuSU-BOLINDET et al. 2011

ŞTEFĂNESCU-ONIŢIU 2008

ŢEPOSU-MARINESCU-PoP 2000
= M. Moltesen-J. Fejfer-L. LeegaArd-J. Lund-B. Lundgreen-A. M. Nielsen (eds): Catalogue Imperial Rome. II.: Statues ny Carlsberg Glyptotek. Carlsberg 2002.

= Kaufmann-Heinimann: Die Römischen Bronzen der Schweiz. I.: Augst, und das Gebiet der Colonia Augusta Raurica. Mainz am Rhein 1977.

$=$ G. Bounegru- R. Ciobanu- R. Ota - D. Anghel: Lux, util şi estetic la Apulum. Podoabe şi accesorii vestimentare. Catalog de expoziţie [Luxury, Useful and Aesthetic at Apulum. Jewelry and Accessories. Exhibition Catalogue]. Alba Iulia 2011.

= J. MEDINI: Rimska brončana plastika u Arheološkom Muzeju u Zadru (Römische Porträtplastik aus der Sammlung Danieli im Archäologischen Museum von Zadar). Diadora 4 (1968) 143-183.

= H. MenZEL: Die römischen Bronzen aus Deutschland. II. : Trier. Mainz 1966.

= H. MEnZEL: Rheinisches Landesmuseum Bonn. Römische Bronzen. Düsseldorf 1969.

$=$ R. OTA: From Beauty to wisdom: votive statues of Venus, Minerva and an unidentified Goddess from Apulum. In: Scripta classica. Radu Ardevan sexagenario dedicata. Eds.: I. Piso, V. RusuBolindeţ, R. Varga, S. Mustaţă, E. Beu-Dachin, L. Ruscu. Cluj-Napoca 2011, 159-167.

$=$ R. OTA: De la canabele legiunii a XIII-a Gemina la Municipium Septimium Apulense [From Canabae Legionis to Municipium Septimium Apulense]. Alba Iulia 2012.

= L. B. PopoviĆ- D. MANO-ZISI-M. VeLIČKoviĆ-B. JeličIĆ: Antička bronza u Jugoslaviji. 1844-1969 [Antique Bronzes from Yugoslavia, 1844-1969]. Beograd 1969.

= G. RACHET-M. F. RACHET: Dictionnaire de la civilisation grecque. Paris 1968 .

= V. Rusu-Bolindeţ-T. Muntean-R. Varga-I. Strîmbu-G. Bounegru : Palatul guvernatorului Daciei romane de la Apulum. O redescoperire a patrimoniului [The Praetorium of Apulum. Rediscovering the Cultural Heritage]. Cluj-Napoca 2011.

= A. ŞTEFĂNESCU-OniţıU: Ateliere de prelucrare a bronzului, argintului şi aurului în Dacia Romană [Workshops for the processing of bronze, silver and gold in Roman Dacia]. In: Dacia în sistemul socio-economic roman. $\mathrm{Cu}$ privire la atelierele meşteşugăreşti locale [Dacia in the Roman SocioEconomic System. Regarding to the local workshops]. Eds: D. Benea, S. Regep-Vlascici, M. Crînguş-Balaci, A. Ştefănescu-Oniţiu, C. Timoc. Bibliotheca historica et archaeologica Universitatis Timisiensis 9. Timişoara 2008, 180-214.

= L. ŢEPOSU-MARINESCU-C. PoP: Statuete de bronz din Dacia romană [Bronze Statuettes from Roman Dacia]. I. Bucharest 2000 